\title{
PERANCANGAN APLIKASI MEDIA INTERAKTIF BERBASIS MOBILE SEBAGAI PENGENALAN ARTEFAK MUSEUM
}

\author{
I Kadek Aridena Putera ${ }^{1}$, Anak Agung Ayu Putri Ardyanti ${ }^{2}$, Ketut Queena Fredlina ${ }^{3}$, Wawan Sujarwo ${ }^{4}$ \\ I Putu Satwika5, Made Pharmawati ${ }^{6}$ \\ 1,2,3 Program Studi Teknik Informatika, STMIK Primakara, ${ }^{4}$ Lembaga IImu Pengetahuan Indonesia, \\ ${ }^{5}$ Program Studi Informatika, STMIK Primakara, ${ }^{6}$ Program Studi Biologi, Universitas Udayana \\ aridenaputra@gmail.com ${ }^{1}$, putri.ardyanti@primakara.ac.id ${ }^{2}$, naa.queena@gmail.com ${ }^{3}$, \\ wawan.sujarwo@lipi.go.id ${ }^{4}$, satwika@primakara.ac.id ${ }^{5}$, made_pharmawati@unud.ac.id ${ }^{6}$
}

\begin{abstract}
Abstrak
Museum merupakan tempat untuk melihat informasi, koleksi benda, dan peristiwa-peristiwa dari masa lalu. Museum Panca Yadnya menjadi salah satu museum yang menyimpan artefak kebudayaan di Bali. Saat ini museum tidak dibuka untuk umum karena masih minimnya petugas yang berjaga. Sehingga perlu adanya akses informasi bagi masyarakat umum agar mengetahui koleksi artefak yang ada di museum mengingat pentingnya nilai artefak yang dimiliki museum Panca Yadnya. Melalui pemanfaatan teknologi dengan perancangan aplikasi media interaktif, informasi tentang museum dan koleksinya tetap dapat diakses oleh masyarakat dengan lebih mudah dan lebih menyenangkan. Pembuatan aplikasi dilakukan menggunakan Construct 2 dan dirancang menggunakan metode pengembangan multimedia Luther-Sutopo dengan tambahan tahap maintenance. Aplikasi dibuat dalam bentuk media interaktif yang berguna untuk menampilkan dan memberikan penjelasan tentang informasi dari koleksi yang terdapat pada museum dengan lisan maupun tulisan melalui smartphone. Sampai dengan tahap akhir, aplikasi dapat berjalan dengan baik dan mampu memberikan informasi sesuai dengan yang diharapkan.
\end{abstract}

Kata Kunci: aplikasi, artefak, media interaktif, museum

\begin{abstract}
A museum is a place to see a piece of information, a collection of valuable objects, and past events. The Panca Yadnya Museum is one of the museums that store cultural artifacts in Bali. At the moment, the museum is not open to the public due to the lack of officers on duty, so it needs information access to the public so that the public could recognize the artifact collection on the museum, considering the important value of the artifact owned by the Panca Yadnya museum. By utilization technology with design application interactive media, information about the museum and the collection could still be accessed by the public more easily and more enjoyable. The build of an application is done by using Construct 2 and designed using the multimedia Luther-Sutopo method with the additional maintenance step. Application is made in the form of interactive media that is useful for displaying and providing explanations about information from collections that were contained in the museum using verbal nor writing via smartphone. Until the final step, the application can run well and be able to provide information as expected.
\end{abstract}

Keywords: application, artifact, interactive media, museum 


\section{PENDAHULUAN}

Teknologi terus berkembang ke arah yang lebih baik, teknologi dapat membantu manusia dalam melakukan aktivitas sehari-hari. Smartphone menjadi contoh kecil dari teknologi yang ada saat ini, selain memiliki kegunaan yang cukup luas, melalui smartphone kini semua orang dapat mengetahui informasi dengan sangat cepat dari berbagai belahan dunia dengan menggunakan koneksi internet. Dengan meningkatnya jumlah pengguna internet di Indonesia, sudah mulai banyak situs yang menyediakan bahan-bahan untuk belajar. Hal ini membuat para pengguna internet yang sebagian besar adalah pelajar dapat memanfaatkan internet sebagai sumber belajar dengan mengakses berbagai referensi, baik referensi yang berupa hasil penelitian, maupun artikel hasil kajian dalam berbagai bidang (Zaharnita, Witarsa, \& Rosyid, 2016). Tidak hanya melalui internet, mendapatkan informasi juga bisa dilakukan dengan cara mengunjungi objek wisata, seperti kebun binatang dan juga museum.

Museum merupakan tempat untuk melihat informasi, koleksi benda, dan peristiwaperistiwa dari masa lalu. Menurut Peraturan Pemerintah No. 66 Tahun 2015 definisi museum adalah lembaga yang berfungsi melindungi, mengembangkan, memanfaatkan koleksi, dan mengomunikasikannya kepada masyarakat. Koleksi museum adalah benda, bangunan, struktur cagar budaya yang mempunyai nilai penting bagi sejarah, ilmu pengetahuan, pendidikan, agama, kebudayaan, teknologi, dan pariwisata. Dengan demikian museum memiliki peran dalam menjaga dan melestarikan kebudayaan nasional.

Museum Panca Yadnya menjadi salah satu museum yang menyimpan artefak kebudayaan di Bali. Museum Panca Yadnya diresmikan pada tanggal 17 Juli 2018 oleh Deputi Ilmu Pengetahuan Hayati LIPI, Enny Soedarmonowati. Di museum ini pengunjung dapat mempelajari tentang lima kelompok upacara Hindu dan melihat berbagai artefak yang digunakan dalam upacara tradisional masyarakat Hindu Bali. Museum Panca Yadnya berlokasi di dalam kompleks Kebun Raya Eka Karya Bedugul Bali yang memiliki luas 157,5 Ha (LIPI, 2018). Berdasarkan data pengunjung Bedugul, kunjungan wisatawan dari tahun 2003-2013 mengalami fluktuasi (Purnama \& Ardyanti, 2017). Saat ini Museum Panca Yadnya tidak di buka untuk umum, hal ini juga disampaikan oleh Bapak Dr. Wawan Sujarwo selaku Peneliti Ahli Madia. Menurut Bapak Wawan, museum belum dibuka untuk umum karena masih minimnya petugas yang berjaga. Saat berkunjung ke Museum Panca Yadnya, terlihat banyak benda-benda bersejarah yang sehari-hari jarang ditemui. Semua barang koleksi dilengkapi dengan keterangan seperti bahan, kegunaan dan juga asal dari masing-masing benda yang terdapat di museum. Dengan kondisi museum yang saat ini tidak dibuka untuk umum, tidak semua masyarakat bisa mendapatkan informasi yang terdapat di dalam museum. Memanfaatkan teknologi dalam memperkenalkan museum dapat dijadikan solusi agar museum dapat diketahui oleh masyarakat umum. Informasi yang tersedia dapat diolah agar bisa menjadi media pembelajaran yang menyenangkan. Saat ini dirasakan betapa pentingnya pemanfaatan teknologi dalam kegiatan pembelajaran untuk meningkatkan kualitas pembelajaran (Banindro, 2019). 
Pemanfaatan teknologi melalui media interaktif merupakan salah satu penyampaian informasi yang mudah menarik perhatian. Dalam penggunaannya, terdapat hubungan timpal balik antara media dan mengguna media (Kusmanagara, Marisa, \& Wijaya, 2018). Media interaktif dapat disajikan dengan menggabungkan antara teks, gambar, audio dan video. Menarik atau tidak sebuah media interaktif tergantung kepada penyampaian dari aplikasi media interaktif yang dibuat, sehingga dibutuhkan perancangan yang matang sebelum mulai membuat aplikasi. Setelah aplikasi selesai dibuat, aplikasi harus diuji agar diketahui seberapa layak aplikasi tersebut akan digunakan.

Perancangan aplikasi media interaktif pada Museum Panca Yadnya sangat memungkinkan untuk dilakukan. Berdasarkan observasi yang dilakukan pada Museum Panca Yadnya, didapatkan beberapa data berupa teks dan gambar, dengan data tersebut dapat dikembangkan menjadi audio dan juga animasi. Dengan adanya aplikasi media interaktif berbasis mobile dapat memberikan informasi kepada masyarakat umum, sekaligus memperkenalkan keberadaan dari Museum Panca Yadnya. Aplikasi dibuat dalam bentuk media interaktif yang berguna untuk menampilkan dan memberikan penjelasan tentang informasi dari koleksi yang terdapat pada museum dengan lisan maupun tulisan melalui smartphone. Walaupun saat ini museum tidak dibuka untuk umum namun tetap dapat mengkomunikasikan kepada masyarakat apa saja yang terdapat di dalam museum sesuai dengan Peraturan Pemerintah No. 66 Tahun 2015 tentang fungsi museum.

Penggunaan media interaktif sebagai media informasi sudah dilakukan pada beberapa penelitian, seperti penelitian dengan judul "Multimedia Interaktif Sebagai Media Informasi Mengenai Pengenalan Energi Alternatif" (Arifin \& Fadhlillah, 2017). Penelitian tersebut bertujuan memberikan informasi dan pengenalan seputar energi alternatif dengan menggunakan media interaktif. Kesimpulan penelitian tersebut cukup baik dan membuat pengguna menjadi tertarik dalam menggunakannya sebagai sarana pengenalan energi alternatif serta pengembangannya. Selain dapat dijadikan media informasi, media interaktif juga dapat membantu dalam proses pembelajaran siswa agar lebih menarik. Penelitian dengan judul "Pengembangan Multimedia Pembelajaran Interaktif Menggunakan Construct 2 Tentang Suhu Dan Kalor Untuk Siswa Kelas X SMA" (Maharani, 2018) menggunakan multimedia interaktif untuk menghilangkan rasa bosan dan jenuh dari siswa. Siswa lebih berminat jika penyampaian informasi/materi pembelajaran dibuat secara menarik, sehingga siswa merasa senang untuk memahami pelajaran. Berdasarkan validasi yang dilakukan pada tiga sekolah, diperoleh rata-rata $85,7 \%$ dengan kategori sangat baik.

\section{METODE PENELITIAN}

Penelitian ini menggunakan pendekatan kualitatif dengan tujuan menggali lebih dalam apa saja yang dapat dikembangkan dari data terdapat pada Museum Panca Yadnya. Dalam mengumpulkan data dan informasi saat pembuatan aplikasi, akan dilakukan beberapa teknik pengumpulan data yaitu, wawancara, observasi dan studi literatur. Sedangkan untuk mengukur penilaian pengguna terhadap aplikasi akan digunakan kuesioner. Populasi penelitian dalam penyebaran kuesioner adalah wisatawan domestik 
yang pernah mengunjungi Kebun Raya Eka Karya Bedugul Bali. Untuk batas usia wisatawan tersebut adalah mulai dari usia 11 tahun dan tidak lebih dari usia 50 tahun.

Aplikasi media interaktif berbasis mobile dibuat menggunakan aplikasi Construct 2 . Penggunaan Constuct 2 dapat menghasilkan produk multimedia interaktif yang layak digunakan (Maharani, 2018). Aplikasi akan dirancang menggunakan metode pengembangan multimedia Luther-Sutopo dengan tambahan tahap maintenance yang dikembangkan oleh Untoro dalam penelitiannya. Tahap maintenance menjadi tahap opsional yang akan dilakukan jika terdapat bug dan masukan dari pengguna (Untoro, 2019). Sehingga terdapat 7 tahap yang akan dijalankan dalam melakukan penelitian ini.

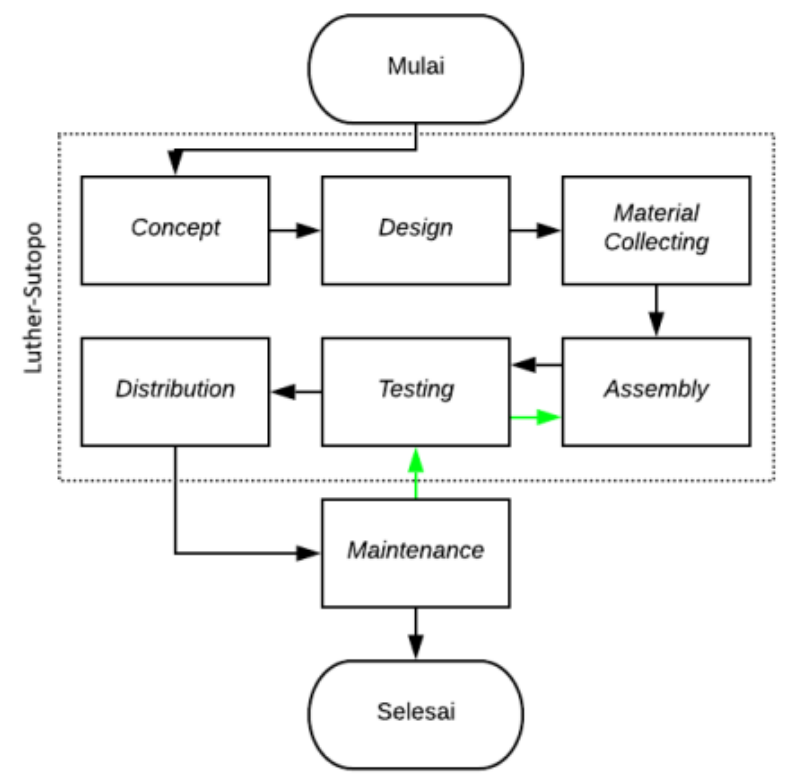

Gambar 1. Alur penelitian dengan metode Luther-Sutopo [Sumber: Dokumentasi Penulis]

Teknik pemilihan sampel yang digunakan pada penelitian ini adalah teknik probability sampling tipe simple random sampling. Untuk menentukan sampel akan digunakan rumus yang dikemukakan oleh Hadari Nawawi (Untoro, 2019).

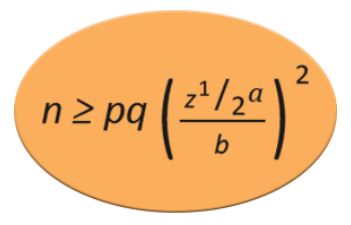

Gambar 2. Rumus probability sampling

[Sumber: Untoro, 2019]

Diketahui beberapa nilai yang akan digunakan dalam menghitung sample, pada tahun 2017 diketahui jumlah pengunjung Kebun Raya Eka Karya Bedugul Bali sebanyak 384.064 pengunjung yang terdiri dari pengunjung lokal dan domestik (LIPI, 2017). Untuk wisatawan domestik yang berkunjung ke Bali pada tahun 2017 tercatat sejumlah 8.735.633 orang (Badan Pusat Statistik Provinsi Bali, 2019a). Sedangkan perkiraan jumlah penduduk Bali pada tahun 2017 sekitar 4.246.500 orang (Badan Pusat Statistik 
Provinsi Bali, 2019b). Kemungkinan tingkat kekeliruan dalam penelitian ini adalah 5\%, sehingga Z1/2 $\alpha$ adalah 1.96. Dari data yang telah diketahui, selanjutnya akan dicoba dimasukkan ke dalam rumus.

Diketahui:

pengunjung $=$ Pengunjung Kebun Raya Eka Karya Bedugul Bali tahun $2017=384.064$

wisatawandomestik = Wisatawan domestik yang berkunjung ke Bali $=8.735 .633$

penduduk $=$ Perkiraan jumlah penduduk Bali $=4.246 .500$

$p=\frac{\text { pengunjung }}{\text { (wisatawan domestik }+ \text { penduduk) }}$

$p=\frac{384.064}{(8.735 .633+4.246 .500)}=0.03$

$\mathrm{q} \quad=1-\mathrm{p}$

$=0.97$

$\mathrm{Z}^{1} / 2 \alpha=1,96$

b $\quad=5 \%=0.05$

maka,

$n \geq p q\left(\frac{z^{1 / 2} \alpha}{b}\right)^{2}$

$n \geq(0,03)(0,97)(1536,64)$

$n \geq 44.7$

Berdasarkan perhitungan yang telah dilakukan, didapatkan total sampel yang akan digunakan dalam penelitian ini minimal sebanyak 45 orang wisatawan atau masyarakat umum yang pernah mengunjungi Kebun Raya Eka Karya Bedugul Bali dengan rentang umur 11 tahun sampai 50 tahun. Sesuai dengan yang dikemukakan Roscoe, bahwa ukuran sampel yang layak dalam penelitian adalah antara 30 sampai dengan 500 (Nuryati, 2015). Kuesioner yang diberikan kepada responden akan diuji validitas dan reliabilitas.

\section{HASIL DAN PEMBAHASAN}

Penelitian dilakukan menggunakan metode Luther-Sutopo ditambah dengan tahap maintenance. Setiap langkah akan dilakukan dengan urut agar mendapatkan hasil sesuai dengan yang diinginkan.

\subsection{Tahap Concept}

Tahap konsep dilakukan dengan cara observasi dan juga wawancara yang dilakukan terhadap Bapak Dr. Wawan Sujarwo selaku Peneliti Ahli Madia. Dari observasi dan wawancara yang dilakukan, dapat disimpulkan bahwa untuk saat ini Museum Panca Yadnya tidak dibuka untuk umum. Namun, Bapak Wawan menginginkan agar museum ini tetap dapat memberikan informasi dan edukasi kepada masyarakat secara umum. Selain itu, terdapat beberapa data yang diterima saat berkunjung ke Museum Panca Yadnya. Data tersebut berupa file excel yang dimiliki oleh pihak museum dan foto yang didapatkan pada saat berkunjung ke museum. 
Setelah melakukan observasi dan wawancara, maka dapat dikonsepkan sebuah aplikasi media interaktif berbasis mobile yang dapat membantu memberikan edukasi kepada masyarakat secara umum dan juga dapat menjadi media promosi terkait dengan keberadaan dari Museum Panca Yadnya. Aplikasi yang akan dibuat dapat menampilkan informasi artefak yang terdapat pada museum. Informasi tersebut berupa gambar, deskripsi dan juga narasi suara dari artefak. Semua data tersebut akan menggunakan data yang diberikan oleh pihak museum per tanggal 7 Januari 2019. Aplikasi media interaktif ini nantinya akan berada dalam sebuah sistem yang saling terintegrasi satu sama lain dengan aplikasi yang berkaitan dengan Kebun Raya Eka Karya Bedugul Bali, seperti Sistem Informasi Tanaman Obat, game Bedugul Forest dan game Pengenalan Lingungan Kebun Raya Eka Karya Bedugul Bali.

\subsection{Tahap Design}

Pada tahap design, tampilan awal aplikasi sudah mulai terbentuk dan akan menjelaskan secara detail tentang fitur dan operasi-operasi dalam menjalankan aplikasi. Hal tersebut bertujuan untuk mempermudah dalam melakukan tahap selanjutnya. Tahap ini dikerjakan sesuai dengan rancangan aplikasi yang telah dibuat sebelumnya. Design rancangan ini masih berupa gambar yang dibuat menggunakan software Adobe Photoshop, sehingga belum adanya interaksi antar halaman.

\subsubsection{Desain Tampilan Flash Screen}

Desain tampilan flash screen pada saat aplikasi pertama kali dibuka. Pada aplikasi ini, tampilan flash screen dibuat dengan tampilan sederhana yang hanya berisi logo.

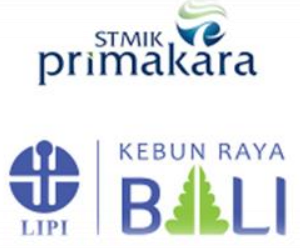

Gambar 3. Desain tampilan flash screen

[Sumber: Dokumentasi Penulis]

\subsubsection{Desain Tampilan Halaman Utama}

Desain halaman utama dibuat menyerupai suasana dalam sebuah museum. Logo dari aplikasi diambil dari bentuk ukiran yang terdapat pada pintu masuk Museum Panca Yadya.

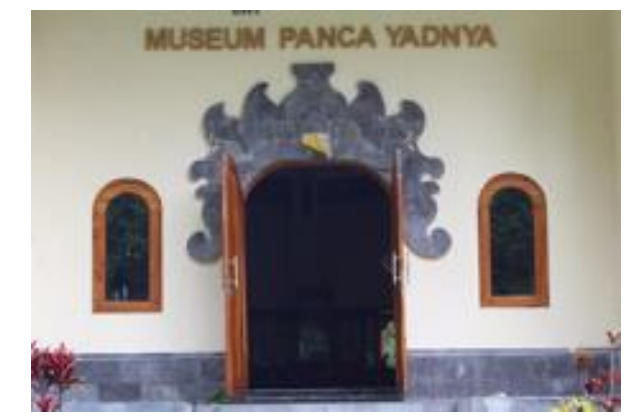

Gambar 4. Dokumentasi pintu masuk museum [Sumber: Dokumentasi Penulis] 
Terdapat beberapa tombol dan fitur yang memiliki fungsinya masing-masing. Penjelasan masing-masing tombol dan fitur pada halaman utama, yaitu:

a. Tombol Masuk: Berfungsi untuk menuju halaman pemilihan lemari dari koleksi artefak museum.

b. Tombol Game: Berfungsi untuk menuju halaman pemilihan game.

c. Tombol Suara: Berfungsi untuk mematikan atau menghidupkan backsound aplikasi.

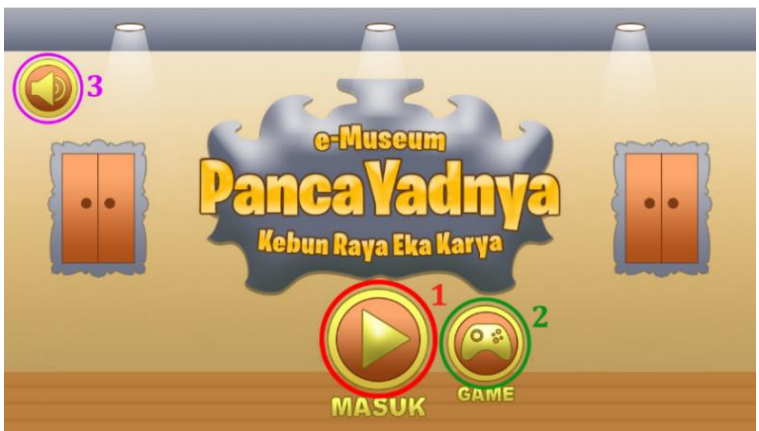

Gambar 5. Desain tampilan halaman utama

[Sumber: Dokumentasi Penulis]

\subsubsection{Desain Tampilan Halaman Lemari}

Pada desain halaman lemari, setiap lemari dikelompokkan sesuai dengan kategori artefak yang ada. Pada halaman ini terdapat pop up denah lemari sesuai dengan posisi yang terdapat pada Museum Panca Yadnya. Terdapat beberapa tombol dan fitur yang memiliki fungsinya masing-masing. Penjelasan masing-masing tombol dan fitur pada halaman ini, yaitu:

a. Lemari: Berfungsi untuk masuk ke halaman detail artefak sesuai dengan kategori masing-masing. Setiap lemari memiliki kategori yang berbeda-beda.

b. Tombol Kembali: Berfungsi untuk kembali ke halaman utama.

c. Tombol Denah: Berfungsi untuk menampilkan pop up denah.

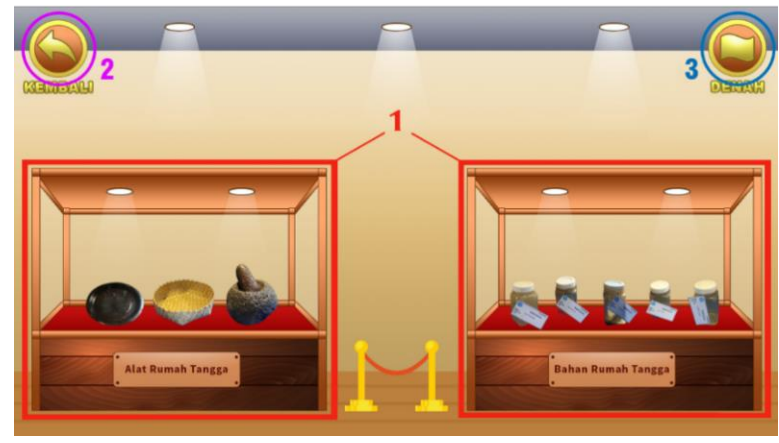

Gambar 6. Desain tampilan halaman lemari [Sumber: Dokumentasi Penulis]

Pada halaman lemari terdapat enam jenis lemari yang dibagi berdasarkan kategori masing-masing artefak. Karena tidak memungkinkan menempatkan enam lemari pada satu halaman, maka halaman lemari ini dibagi menjadi tiga. Pengguna dapat melakukan swipe untuk melihat pilihan lemari yang lain. 


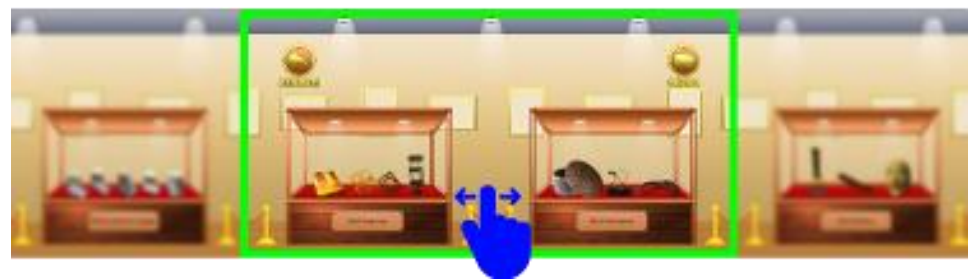

Gambar 7. Swipe gesture pada tampilan halaman lemari [Sumber: Dokumentasi Penulis]

\subsubsection{DesainTampilan Pop Up Denah}

Desain pop up denah mengambil tampilan dari posisi lemari sesuai dengan yang terdapat pada Museum Panca Yadnya. Pada pop up ini terdapat beberapa tombol dan fitur yang memiliki fungsinya masing-masing. Penjelasan masing-masing tombol dan fitur pada pop up ini, yaitu:

a. Tombol Nama Lemari: Masing-masing tombol yang berisi nama lemari dapat di klik dan menampilkan deskripsi yang berbeda-beda. Selain menampilkan deskripsi dari lemari yang dipilih, aplikasi akan langsung memutar narasi berupa suara sesuai dengan lemari yang dipilih.

b. Tombol Suara: Berfungsi untuk memutar ulang narasi berupa suara sesuai dengan nama lemari yang dipilih.

c. Tombol Tutup: Berfungsi untuk menutup pop up dan kembali ke halaman lemari.

d. Deskripsi Lemari: Deskripsi lemari akan berubah sesuai dengan lemari yang dipilih.

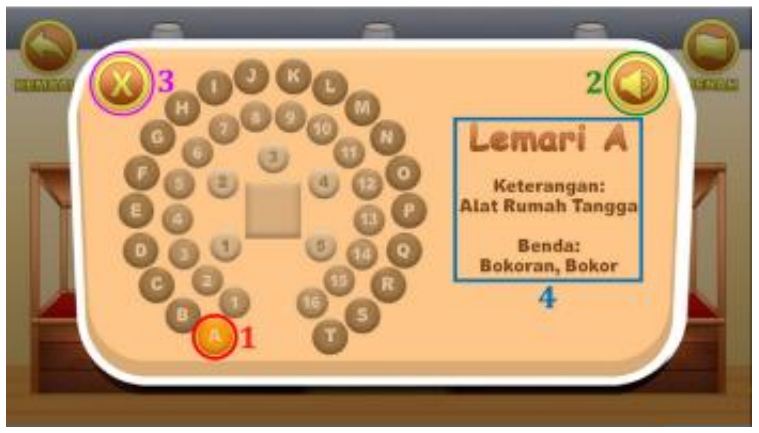

Gambar 8. Desain tampilan pop up denah [Sumber: Dokumentasi Penulis]

\subsubsection{Desain Tampilan Halaman Detail}

Desain halaman detail artefak akan menampilkan detail dari artefak berdasarkan kategori yang dipilih pada halaman lemari. Pada halaman ini terdapat beberapa tombol dan fitur yang memiliki fungsinya masing-masing. Penjelasan masing-masing tombol dan fitur pada halaman ini, yaitu:

a. Tombol Sebelumnya: Berfungsi untuk melihat artefak sebelumnya.

b. Tombol Selanjutnya: Berfungsi untuk melihat artefak selanjutnya.

c. Tombol Kembali: Berfungsi untuk kembali ke halaman lemari.

d. Tombol Suara: Berfungsi untuk memutar ulang narasi berupa suara sesuai dengan artefak yang tampil. 
e. Gambar Artefak: Gambar artefak sesuai dengan kategori lemari yang dipilih pada halaman lemari.

f. Deskripsi Artefak: Deskripsi artefak akan ikut berubah sesuai dengan gambar artefak yang tampil.

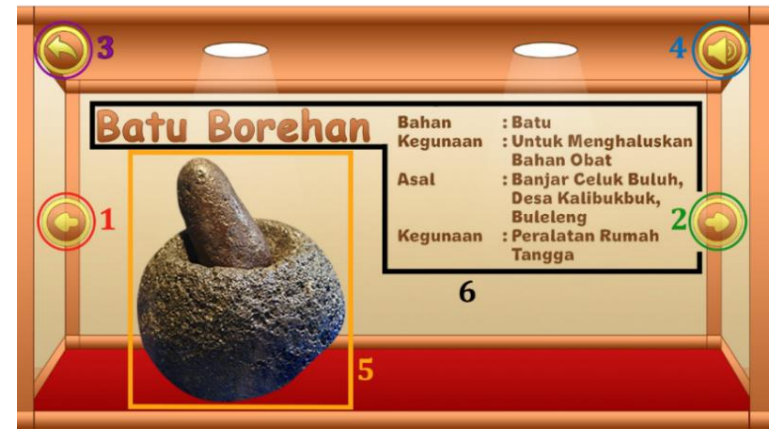

Gambar 9. Desain tampilan halaman detail

[Sumber: Dokumentasi Penulis]

\subsubsection{Desain Tampilan Halaman Menu Game}

Desain halaman menu game akan menampilkan pilihan game terkait dengan museum. Pada penelitian ini hanya akan terdapat satu pilihan game yang dapat dimainkan. Pilihan game lain akan langsung diarahkan menuju Playstore. Game lain tersebut merupakan salah satu dari sistem terintegrasi yang terdapat pada Kebun Raya Eka Karya Bedugul Bali. Terdapat beberapa tombol dan fitur seperti yang memiliki fungsinya masingmasing. Penjelasan masing-masing tombol dan fitur pada halaman ini, yaitu:

a. Pilihan Game 1: Berfungsi untuk menuju gameplay dari game mencocokkan.

b. Pilihan Game 2: Berfungsi untuk membuka aplikasi Playstore dan diarahkan untuk mengunduh game Bedugul Forest.

c. Tombol Kembali: Berfungsi untuk kembali ke halaman utama.

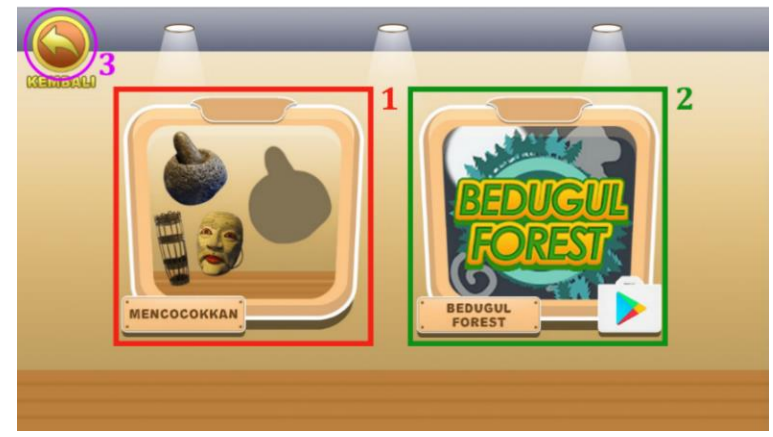

Gambar 10. Desain tampilan halaman game

[Sumber: Dokumentasi Penulis]

\subsubsection{Desain Tampilan Gameplay}

Desain halaman gameplay, permainan yang terdapat pada aplikasi adalah permainan mencocokkan bentuk. Tujuan dari permainan ini adalah untuk menarik minat dari anakanak yang akan menggunakan aplikasi. Pada tampilan gameplay ini terdapat beberapa tombol dan fitur yang memiliki fungsinya masing-masing. Penjelasan masing-masing tombol dan fitur pada halaman ini, yaitu: 
a. Pilihan Jawaban: Gambar-gambar artefak yang merupakan pilihan jawaban yang dapat di drag and drop menuju bagian soal.

b. Pertanyaan/Soal: Gambar yang rubah menjadi hitam yang dapat merupakan pertanyaan dari dan harus dicocokkan dengan jawaban yang terdapat di sebelahnya.

c. Tombol Kembali: Berfungsi untuk kembali ke halaman menu game.

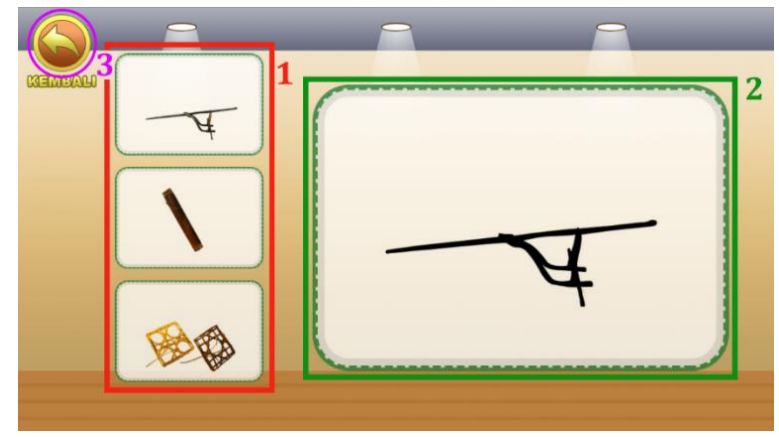

Gambar 11. Desain tampilan halaman game

[Sumber: Dokumentasi Penulis]

\subsection{Tahap Material Collecting}

Pada tahap material collecting, semua bahan yang akan digunakan untuk membuat aplikasi dikumpulkan dan dikelompokkan sesuai dengan kegunaan dan formatnya masing-masing. Tujuan dari tahap ini untuk mempermudah dalam proses assembly. Material yang dikelompokkan sesuai dengan file Excel yang diberikan pihak museum. Sebelum mulai pengelompokan material, data file Excel distandarisasi terlebih dahulu.

Software yang digunakan dalam membuat asset gambar aplikasi adalah Adobe Photosshop. Gambar artefak yang telah didapatkan pada Museum Panca Yadnya dicocokkan terlebih dahulu dengan file excel yang telah diberikan. Hal ini dilakukan agar dapat mengelompokkan gambar artefak yang didapat dengan keterangan dari masingmasing artefak. Setelah selesai mencocokkan data, selanjutnya masuk ke tahap pemotongan gambar. Gambar akan dipotong supaya terlihat lebih menarik dan menyatu dengan tampilan aplikasi. Gambar artefak yang telah dipotong lalu disimpan dalam format .png agar gambar dapat dilihat dengan background transparan. Proses ini membutuhkan waktu paling lama diantara proses yang lain.

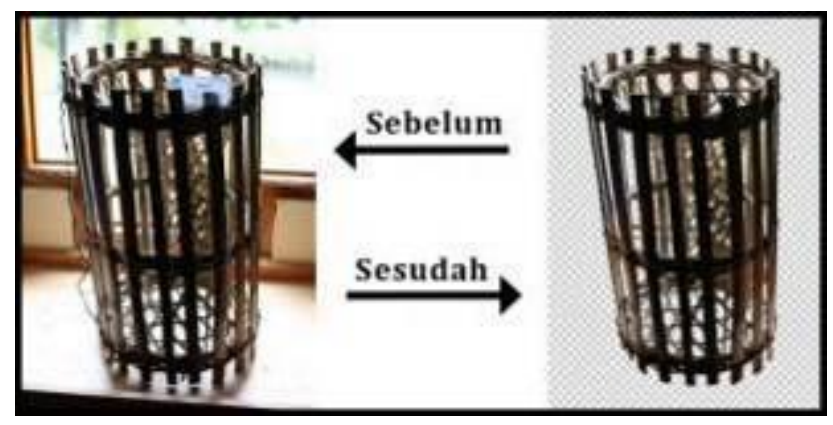

Gambar 12. Contoh hasil pemotongan gambar artefak [Sumber: Dokumentasi Penulis] 
Selain menyiapkan gambar artefak, asset gambar yang telah dikerjakan pada tahap design juga disimpan menjadi beberapa file. File yang disimpan berupa background dan tombol.

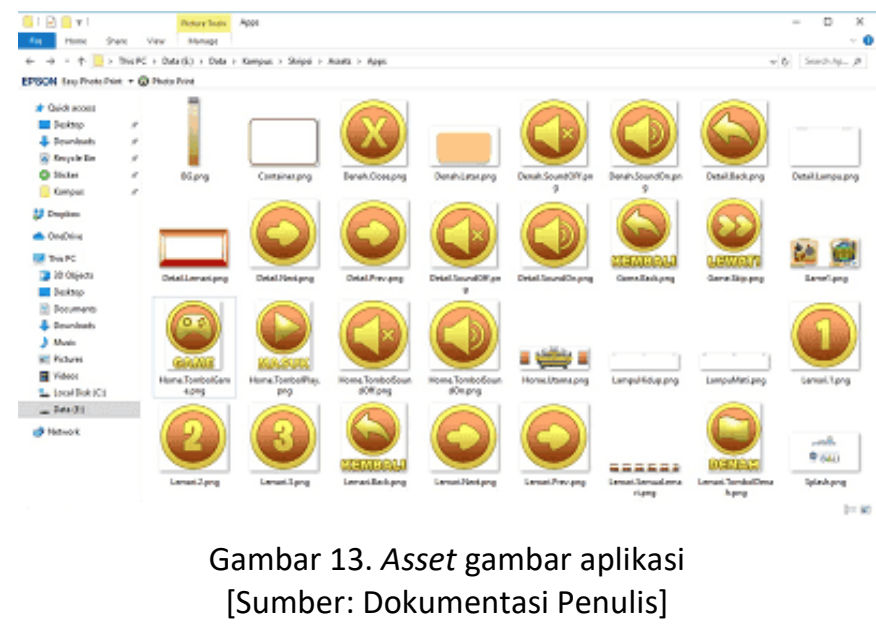

Setelah semua material gambar terkumpul, selanjutnya dilakukan proses compress. Hal ini dilakukan agar ukuran akhir dari aplikasi tidak terlalu besar, karena banyaknya data gambar yang dibutuhkan aplikasi. Proses ini dilakukan menggunakan software Pngyu. Pengujian yang dilakukan mampu mengurangi ukuran gambar hingga $70 \%$.

\subsection{Tahap Assembly}

Pada tahap assembly, aplikasi akan dibangun menggunakan software Construct 2. Construct 2 dipilih karena cara penggunaannya hanya memerlukan drag \& drop. Selain itu Construct 2 juga dikenal sebagai aplikasi pembuat game, sehingga dapat dengan mudah menambahkan game sederhana kedalam aplikasi. Aplikasi dibuat menggunakan resolusi layar 1280 x 720 pixel. Format file yang dihasilkan oleh Construct 2 adalah HTML 5, sehingga diperlukan compiler untuk dapat merubahnya menjadi file .apk. Compiler yang digunakan adalah Phonegap.com. Sebelum melakukan Compile, project yang dibuat harus di export terlebih dahulu, lalu digabungkan menjadi format .zip agar dapat di upload pada Phonegap.com.

\subsection{Tahap Testing}

Untuk menguji aplikasi, digunakan pengujian black box yang berguna untuk memastikan semua fitur yang diinginkan berjalan sesuai dengan perencanaan awal. Pengujian black box dilakukan pada saat aplikasi sudah dapat digunakan, pengujian ini dibagi menjadi tiga. Fase pertama akan dilakukan pengujian kepada pihak-pihak yang berhubungan langsung dengan aplikasi yang dibangun. Tujuan dilakukannya fase pertama ini adalah untuk melihat kelayakan dari tampilan aplikasi. 
Tabel 1. Pengujian Black Box fase pertama [Sumber: Dokumentasi Penulis]

\begin{tabular}{|l|l|}
\hline \multicolumn{1}{|c|}{ Bagian Pengujian } & \multicolumn{1}{c|}{ Revisi } \\
\hline Judul aplikasi & $\begin{array}{l}\text { Judul dengan kata “Panca Yadnya” kurang dikenal oleh } \\
\text { masyarakat di luar daerah Bali. }\end{array}$ \\
\hline Tampilan halaman depan & Rubah tampilan yang lebih menyerupai situasi museum. \\
\hline Halaman lemari & Perubahan konsep swipe untuk melihat lemari lainnya. \\
\cline { 2 - 2 } & $\begin{array}{l}\text { Lemari “Diorama Upacara” disesuaikan agar lebih mudah } \\
\text { diketahui masyarakat umum. }\end{array}$ \\
\hline
\end{tabular}

Setelah pengujian fase pertama selesai dilakukan, penelitian akan kembali melalui tahap material collecting dan tahap assembly. Hal ini bertujuan untuk melakukan perbaikan dari hasil revisi yang didapat.

Tabel 2. Hasil revisi pengujian Black Box fase pertama

[Sumber: dokumentasi penulis]

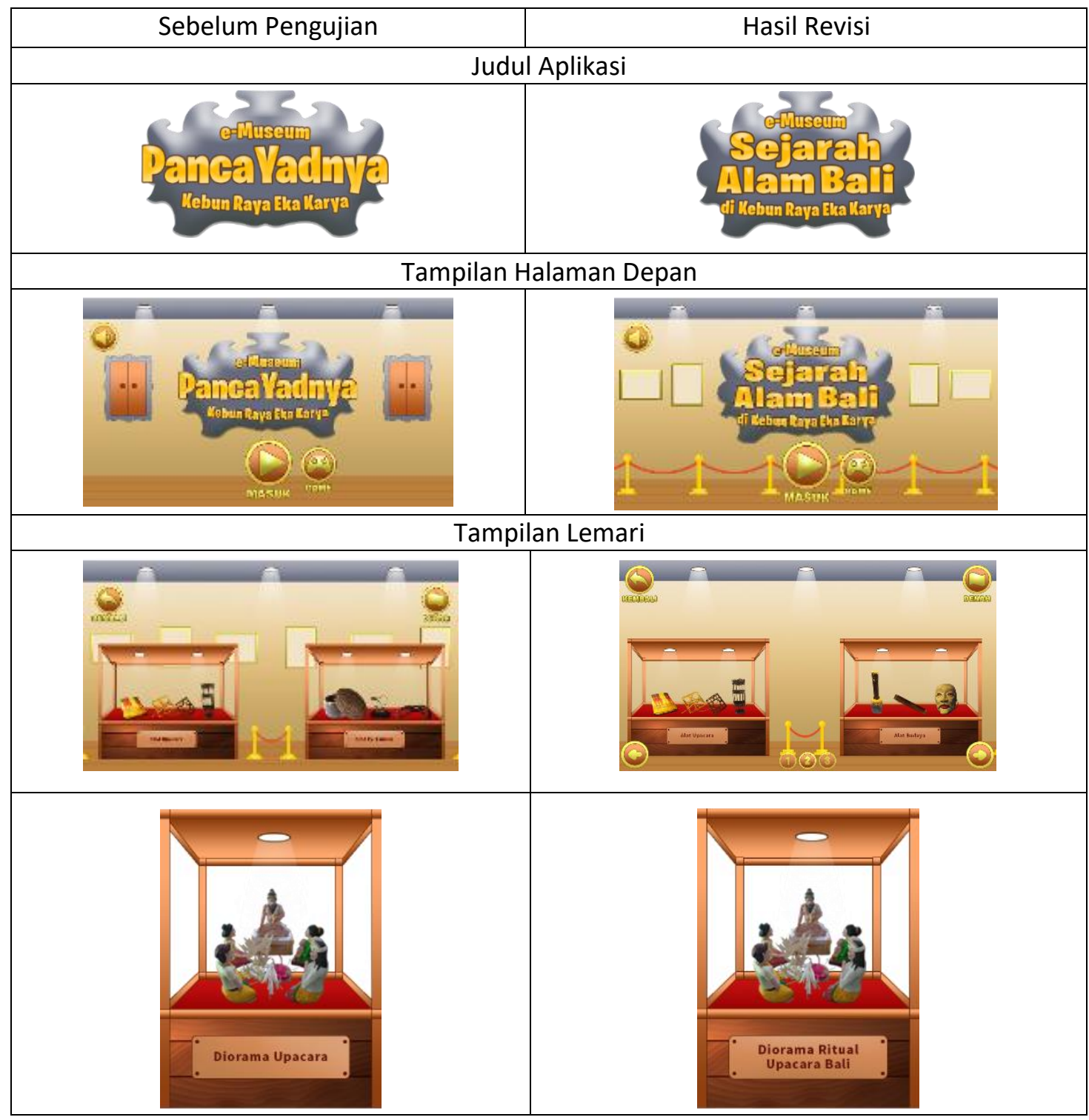


Setelah revisi selesai dikerjakan, pengujian dilanjutkan dengan menguji bagian fungsi dan fitur aplikasi. Pengujian ini meliputi masukan dan keluaran yang telah berfungsi seperti yang diharapkan.

Tabel 3. Hasil pengujian Black Box fase kedua halaman utama

[Sumber: Dokumentasi Penulis]

\begin{tabular}{|c|l|l|l|r|}
\hline No. & \multicolumn{1}{|c|}{ Yang Diuji } & \multicolumn{1}{|c|}{ Input } & \multicolumn{1}{c|}{ Output } & Hasil \\
\hline 1 & Masuk aplikasi & Klik tombol masuk. & Masuk halaman lemari. & {$[\mathrm{V}]$} \\
\hline 2 & Masuk game & Klik tombol game. & Masuk halaman pilih game.. & {$[\mathrm{V}]$} \\
\hline 3 & Matikan musik & Klik tombol musik. & Backsound tidak bersuara. & {$[\mathrm{V}]$} \\
\hline
\end{tabular}

Tabel 4. Hasil pengujian Black Box fase kedua halaman lemari

[Sumber: Dokumentasi Penulis]

\begin{tabular}{|c|l|l|l|c|}
\hline No. & \multicolumn{1}{|c|}{ Yang Diuji } & \multicolumn{1}{|c|}{ Input } & \multicolumn{1}{|c|}{ Output } & Hasil \\
\hline 1 & Lihat denah & Klik tombol denah. & $\begin{array}{l}\text { Menampilkan pop up } \\
\text { denah. }\end{array}$ & {$[\mathrm{V}]$} \\
\hline 2 & Masuk lemari & Klik lemari & $\begin{array}{l}\text { Masuk ke halaman detail } \\
\text { artefak. }\end{array}$ & {$[\mathrm{V}]$} \\
\hline 3 & $\begin{array}{l}\text { Pindah } \\
\text { halaman }\end{array}$ & $\begin{array}{l}\text { Klik tombol halaman/ } \\
\text { halaman selanjutnya. }\end{array}$ & Pindah tampilan halaman. & {$[\mathrm{V}]$} \\
\hline 4 & Kembali & Klik tombol kembali. & Kembali ke halaman utama. & {$[\mathrm{V}]$} \\
\hline
\end{tabular}

Tabel 5. Hasil pengujian Black Box fase kedua pop up denah

[Sumber: Dokumentasi Penulis]

\begin{tabular}{|c|l|l|l|c|}
\hline No. & \multicolumn{1}{|c|}{ Yang Diuji } & \multicolumn{1}{|c|}{ Input } & \multicolumn{1}{|c|}{ Output } & Hasil \\
\hline 1 & $\begin{array}{l}\text { Tampilkan } \\
\text { keterangan lemari } \\
\text { pada denah }\end{array}$ & Klik nama lemari. & $\begin{array}{l}\text { Deskripsi berubah sesuai lemari } \\
\text { dan narasi suara berbunyi } \\
\text { sesuai lemari yang dipilih. }\end{array}$ & {$[\mathrm{V}]$} \\
\hline 2 & $\begin{array}{l}\text { Ulang penjelasan } \\
\text { suara }\end{array}$ & $\begin{array}{l}\text { Klik tombol } \\
\text { suara. }\end{array}$ & $\begin{array}{l}\text { Penjelasan suara diputar } \\
\text { kembali sesuai lemari yang } \\
\text { dipilih. }\end{array}$ & {$[\mathrm{V}]$} \\
\hline 3 & Keluar dari pop up & $\begin{array}{l}\text { Klik tombol close } \\
\text { (X). }\end{array}$ & $\begin{array}{l}\text { Pop up denah menghilang dan } \\
\text { kembali tampil ke halaman } \\
\text { lemari. }\end{array}$ & {$[\mathrm{V}]$} \\
\hline
\end{tabular}

Tabel 6. Hasil pengujian Black Box fase kedua halaman detail

[Sumber: Dokumentasi Penulis]

\begin{tabular}{|c|l|l|l|c|}
\hline No. & \multicolumn{1}{|c|}{ Yang Diuji } & \multicolumn{1}{|c|}{ Input } & \multicolumn{1}{|c|}{ Output } & Hasil \\
\hline 1 & $\begin{array}{l}\text { Otomatis } \\
\text { tampilkan artefak } \\
\text { sesuai kategori } \\
\text { lemari }\end{array}$ & $\begin{array}{l}\text { Otomatis saat } \\
\text { halaman detail } \\
\text { pertama kali } \\
\text { dibuka. }\end{array}$ & $\begin{array}{l}\text { Menampilkan artefak sesuai } \\
\text { kategori beserta keterangan } \\
\text { berupa tulisan dan narasi } \\
\text { suara. }\end{array}$ & {$[\mathrm{V}]$} \\
\hline 2 & $\begin{array}{l}\text { Melihat artefak } \\
\text { selanjutnya }\end{array}$ & $\begin{array}{l}\text { Klik tombol panah } \\
\text { previous/next. }\end{array}$ & $\begin{array}{l}\text { Menampilkan artefak } \\
\text { selanjutnya sesuai kategori } \\
\text { lemari yang dipilih. }\end{array}$ & {$[\mathrm{V}]$} \\
\hline
\end{tabular}




\begin{tabular}{|c|l|l|l|c|}
\hline No. & \multicolumn{1}{|c|}{ Yang Diuji } & \multicolumn{1}{c|}{ Input } & \multicolumn{1}{c|}{ Output } & Hasil \\
\hline 3 & $\begin{array}{l}\text { Ulang penjelasan } \\
\text { suara }\end{array}$ & Klik tombol suara. & $\begin{array}{l}\text { Penjelasan suara diputar } \\
\text { kembali sesuai artefak yang } \\
\text { tampil. }\end{array}$ & {$[\mathrm{V}]$} \\
\hline 4 & Kembali & $\begin{array}{l}\text { Klik tombol } \\
\text { kembali. }\end{array}$ & Kembali ke halaman utama. & {$[\mathrm{V}]$} \\
\hline
\end{tabular}

Tabel 7. Hasil pengujian Black Box fase kedua halaman pilih game

[Sumber: Dokumentasi Penulis]

\begin{tabular}{|c|l|l|l|c|}
\hline No. & \multicolumn{1}{|c|}{ Yang Diuji } & \multicolumn{1}{c|}{ Input } & Output & Hasil \\
\hline 1 & $\begin{array}{l}\text { Game } \\
\text { mencocokkan }\end{array}$ & $\begin{array}{l}\text { Klik game } \\
\text { mencocokkan. }\end{array}$ & $\begin{array}{l}\text { Menuju gameplay } \\
\text { mencocokkan. }\end{array}$ \\
\hline 2 & $\begin{array}{l}\text { Game Bedugul } \\
\text { Forest }\end{array}$ & $\begin{array}{l}\text { Klik game Bedugul } \\
\text { Forest. }\end{array}$ & $\begin{array}{l}\text { Menuju Playstore game } \\
\text { Bedugul Forest. }\end{array}$ & {$[\mathrm{V}]$} \\
\hline 3 & Kembali & Klik tombol kembali. & Kembali ke halaman utama. & {$[\mathrm{V}]$} \\
\hline
\end{tabular}

Tabel 8. Hasil pengujian Black Box fase kedua halaman gameplay

[Sumber: Dokumentasi Penulis]

\begin{tabular}{|c|l|l|l|c|}
\hline No. & \multicolumn{1}{|c|}{ Yang Diuji } & \multicolumn{1}{|c|}{ Input } & \multicolumn{1}{c|}{ Output } & Hasil \\
\hline 1 & Jawaban benar & $\begin{array}{l}\text { Drag and Drop artefak } \\
\text { yang benar menuju soal } \\
\text { artefak. }\end{array}$ & $\begin{array}{l}\text { Jawaban benar, muncul } \\
\text { nama dan penjelasan suara } \\
\text { dari artefak yang dijawab. }\end{array}$ & [V] \\
\hline 2 & Jawaban salah & $\begin{array}{l}\text { Drag and Drop artefak } \\
\text { yang salah menuju soal } \\
\text { artefak. }\end{array}$ & $\begin{array}{l}\text { Jawaban salah, artefak } \\
\text { salah kembali ke posisi } \\
\text { semula. }\end{array}$ & {$[\mathrm{V}]$} \\
\hline 3 & Kembali & Klik tombol kembali. & Kembali ke halaman utama. & [V] \\
\hline
\end{tabular}

Setelah fase aplikasi sudah berjalan sesuai dengan fungsinya, pengujian dilanjutkan kepada calon pengguna aplikasi yang belum mengetahui tentang detail dari aplikasi. Pengujian dilakukan dengan mengirimkan file aplikasi berupa .APK dan meminta feedback dan bukti berupa screen record ketika menjalankan aplikasi. Dari pengujian yang dilakukan kepada 3 orang, didapatkan beberapa saran dan beberapa bug pada aplikasi.

Tabel 9. Hasil pengujian Black Box fase ketiga

[Sumber: Dokumentasi Penulis]

\begin{tabular}{|l|l|}
\hline \multicolumn{1}{|c|}{ Bagian Pengujian } & \multicolumn{1}{c|}{ Saran/Bug } \\
\hline Halaman lemari & Tombol pada denah bisa di klik pada saat denah tidak muncul. \\
\hline Halaman detail & $\begin{array}{l}\text { Posisi artefak halaman detail pada kategori bahan rumah tangga } \\
\text { dan diorama ritual upacara Bali kurang menarik atau berantakan. }\end{array}$ \\
\cline { 2 - 2 } & $\begin{array}{l}\text { Hilangkan tombol previous/next pada lemari yang memiliki satu } \\
\text { artefak. }\end{array}$ \\
\hline Pop up denah & $\begin{array}{l}\text { Data denah tidak sesuai dengan isinya saat user masuk ke halaman } \\
\text { detail dan game. Denah berfungsi jika dibuka pertama kali saat } \\
\text { membuka aplikasi. }\end{array}$ \\
\hline
\end{tabular}




\begin{tabular}{|l|l|}
\hline \multicolumn{1}{|c|}{ Bagian Pengujian } & \multicolumn{1}{c|}{ Saran/Bug } \\
\hline Halaman gameplay & $\begin{array}{l}\text { Berikan tombol untuk melanjutkan soal berikutnya, jeda suara } \\
\text { terlalu lama jika harus mendengarkan penjelasan artefak. }\end{array}$ \\
\cline { 2 - 2 } & Tampilan atau posisi penempatan nama benda kadang tidak rapi. \\
\cline { 2 - 2 } & $\begin{array}{l}\text { Suara yang dimatikan pada halaman utama kembali hidup saat } \\
\text { masuk halaman gameplay. }\end{array}$ \\
\hline Halaman pilih game & $\begin{array}{l}\text { Saat melakukan klik pada game Bedugul Forest, tirai hanya } \\
\text { menutup dan tidak kembali. }\end{array}$ \\
\hline Keluar aplikasi & Berikan tombol atau fitur untuk dapat keluar dari aplikasi. \\
\hline Asset tombol & $\begin{array}{l}\text { Beberapa tombol tidak satu bahasa design dengan tampilan } \\
\text { aplikasi. }\end{array}$ \\
\hline Membuka aplikasi & $\begin{array}{l}\text { Aplikasi tidak dapat dijalankan, selalu keluar aplikasi pada saat } \\
\text { dibuka. }\end{array}$ \\
\hline
\end{tabular}

Setelah pengujian fase ketiga selesai dilakukan, penelitian akan kembali melalui tahap material collecting dan tahap assembly. Hal ini bertujuan untuk melakukan perbaikan dari hasil revisi yang didapat.

Tabel 10. Hasil revisi pengujian Black Box fase ketiga [Sumber: Dokumentasi Penulis]

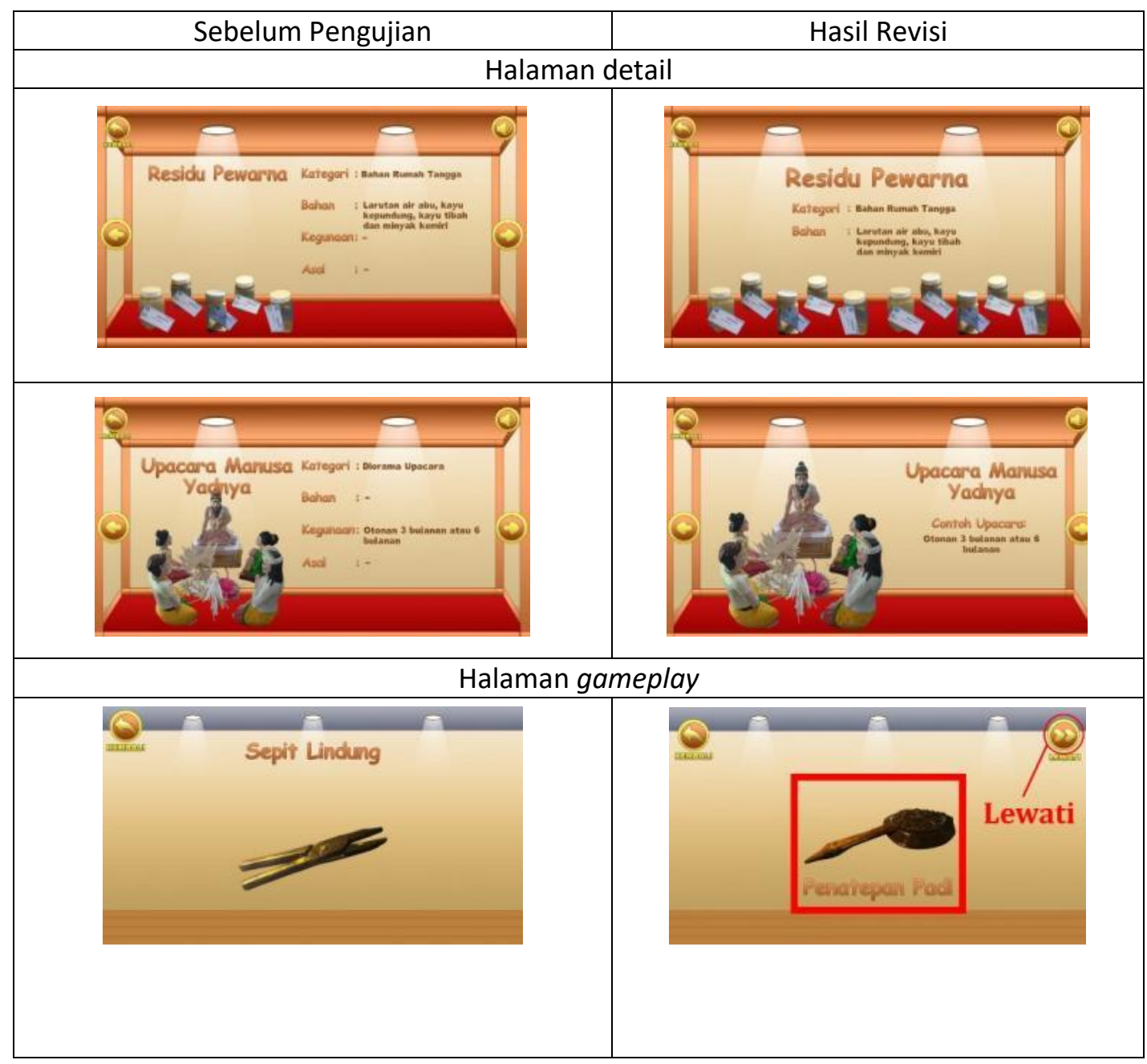




\begin{tabular}{|l|l|l|}
\hline \multicolumn{2}{|c|}{ Sebelum Pengujian } & Hasil Revisi \\
\hline Tidak ada & Peluar aplikasi \\
\hline Asset tombol & Peringatanl \\
Apakah kamu yakin ingin \\
keluar dari aplikasi?
\end{tabular}

\subsection{Tahap Distribution}

Setelah pengujian selesai dilakukan, selanjutnya adalah tahap distribusi dari aplikasi. Aplikasi akan diunggah pada layanan Playstore. Playstore merupakan toko aplikasi utama pada perangkat Android, dengan mendistribusikan melalui Playstore maka aplikasi dapat dengan mudah diakses oleh perangkat Android yang memenuhi syarat minimal spesifikasi.

\subsection{Tahap Maintenance}

Setelah aplikasi melewati tahap distribusi, selanjutnya adalah tahapan maintenance atau perawatan dari aplikasi. Langkah ini merupakan tahapan opsional yang dilakukan jika memang dibutuhkan. Dengan mendistribusikan aplikasi ke dalam layanan Google Playstore, feedback dari pengguna yang mengunduh aplikasi akan dapat dilihat melalui dashboard yang telah disediakan.

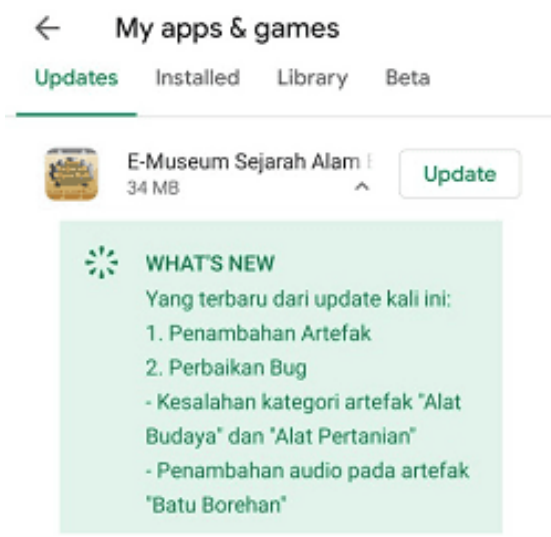

Gambar 14. Update pertama aplikasi [Sumber: dokumentasi penulis]

Dengan banyaknya pengguna smartphone dan jenis smartphone yang digunakan, sangat memungkinkan akan terjadinya perbedaan performa pada penggunaan aplikasi. 
Tujuan dilakukannya tahap maintenance ini adalah untuk memperbaiki bug yang alami oleh pengguna serta untuk meningkatkan performa. Selain untuk menambal bug, maintenance juga diperlukan pada saat pihak museum ingin melakukan update data pada artefak museum atau pembaruan tampilan dari aplikasi. Update aplikasi didistribusikan langsung melalui dashboard yang disediakan pada Google Playstore.

\subsection{Pengujian Kuesioner}

Untuk menguji kuesioner, pengguna akan diberikan sebuah kuesioner agar dapat memberikan penilaian terhadap aplikasi. Kuesioner yang diberikan akan diuji terlebih dahulu sebelum dapat digunakan. Jumlah responden yang digunakan dalam melakukan uji validitas adalah 30 responden. Terdapat 3 aspek yang ditanyakan yaitu aspek tampilan, aspek suara, dan aspek manfaat. Pada setiap aspek mempunyai beberapa buah pertanyaan yang dapat diberikan penilaian dari angka 1 sampai 5 dengan keterangan 1 adalah sangat tidak setuju dan 5 adalah sangat setuju.

Hasil dari kuesioner yang telah dibagikan, akan dihitung menggunakan software IBM SPSS agar dapat diuji validitas dan reabilitasnya. Jika $R$ Hitung $>\mathrm{R}$ Tabel maka item pertanyaan/instrumen dinyatakan valid (Andriyanto, 2016). $\mathrm{R}$ Tabel akan menggunakan sig 0.05 dan menggunakan 30 responden, sehingga didapatkan angka: 0.3061 (Junaidi, 2010).

Setelah selesai melakukan uji validitas, pertanyaan yang sudah valid akan diuji reliabilitas menggunakan IBM SPSS untuk mengetahui nilai Alpha. Jika Nilai Alpha >0.6, maka kuesioner dinyatakan reliabel (Komala \& Nellyaningsih, 2017).

Tabel 11. Uji reliabilitas

[Sumber: Dokumentasi Penulis]

\begin{tabular}{|c|c|c|}
\hline Alpha Cronbach's & Nilai Uji & Hasil \\
\hline 0.855 & 0.6 & Reliabel \\
\hline
\end{tabular}

Nilai Alpa yang didapatkan menggunakan IBM SPSS adalah 0.855. Karena nilai Alpha menunjukkan nilai di atas 0.6 , kuesioner dapat dinyatakan reliabel.

\subsection{Hasil Penilaian}

Dalam penyebaran kuesioner, didapatkan sebanyak 55 responden yang telah memberikan penilaian terhadap aplikasi. Hasil kuesioner akan dikumpulkan dan dihitung untuk dijadikan parameter penilaian terhadap aplikasi. Parameter nilai didapatkan dari total responden dikalikan dengan butir nilai maksimal.

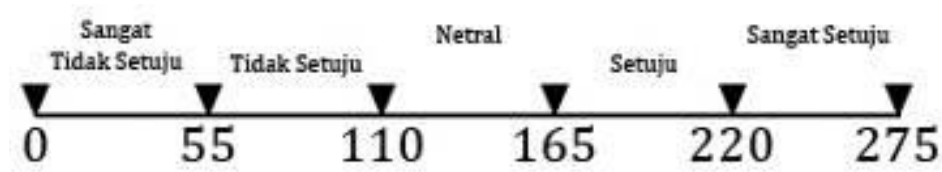

Gambar 15. Diagram parameter respons pengguna [Sumber: Dokumentasi Penulis] 
Tabel 12. Hasil kuesioner penelitian

[Sumber: Dokumentasi Penulis]

\begin{tabular}{|c|c|c|c|}
\hline No & Pernyataan & Nilai & Hasil \\
\hline \multicolumn{4}{|c|}{ Aspek Tampilan } \\
\hline 1 & Pemilihan warna menarik & 248 & Sangat Setuju \\
\hline 2 & Fungsi tombol mudah dipahami & 232 & Sangat Setuju \\
\hline 3 & Tata letak tombol sudah sesuai & 243 & Sangat Setuju \\
\hline 4 & Icon tombol sesuai dengan fungsinya & 248 & Sangat Setuju \\
\hline 5 & Font tulisan mudah dibaca & 236 & Sangat Setuju \\
\hline 6 & Bahasa yang digunakan mudah dipahami & 254 & Sangat Setuju \\
\hline 7 & Fungsi tombol konsisten disetiap halaman & 245 & Sangat Setuju \\
\hline 8 & Animasi transisi antar halaman sudah sesuai & 229 & Sangat Setuju \\
\hline 9 & Aplikasi tidak berat saat dijalankan & 238 & Sangat Setuju \\
\hline 10 & Loading aplikasi cepat & 248 & Sangat Setuju \\
\hline 11 & Tata letak artefak sudah sesuai & 236 & Sangat Setuju \\
\hline 12 & Tata letak deskripsi artefak sudah sesuai & 240 & Sangat Setuju \\
\hline 13 & Tata letak lemari sudah sesuai & 238 & Sangat Setuju \\
\hline 14 & Perpindahan lemari mudah dipahami & 219 & Setuju \\
\hline \multicolumn{4}{|c|}{ Aspek Suara } \\
\hline 15 & Pemilihan backsound sudah sesuai & 242 & Sangat Setuju \\
\hline 16 & Efek suara sudah sesuai & 257 & Sangat Setuju \\
\hline 17 & Narasi suara terdengar jelas & 261 & Sangat Setuju \\
\hline \multicolumn{4}{|c|}{ Aspek Manfaat } \\
\hline 18 & Aplikasi bermanfaat & 251 & Sangat Setuju \\
\hline 19 & Memberikan pengetahuan baru & 256 & Sangat Setuju \\
\hline 20 & Berguna untuk pelajar & 252 & Sangat Setuju \\
\hline & Rata-rata & 243.65 & Sangat Setuju \\
\hline
\end{tabular}

\section{KESIMPULAN}

Aplikasi media interaktif berbasis mobile yang dirancang menggunakan metode pengembangan Luther-Sutopo dengan tambahan tahap maintenance dapat berjalan dengan baik. Segala tahapan berjalan sesuai dengan yang diharapkan, dimulai dari tahap concept yang menjadi tahap paling pertama yang harus dilakukan, sehingga aplikasi memiliki konsep yang sesuai untuk melakukan pengenalan artefak museum. Dilanjutkan dengan tahap desain, tampilan aplikasi sudah mulai terlihat pada tahap ini. Selanjutnya tahap material collecting, dimana seluruh asset yang diperlukan mulai dikumpulkan, setelah asset terkumpul lalu dilanjutkan dengan tahap assembly. Setelah aplikasi sudah dapat dijalankan, dilanjutkan dengan tahap testing, segala kekurangan dari aplikasi akan ditemukan pada tahap ini, maka ada kemungkinan untuk melakukan sebuah revisi dan harus mengulangi dari tahap material collecting dan assembly. Pengulangan langkah dilakukan agar aplikasi yang dibuat dapat berjalan dengan baik tanpa adanya bug. Setelah dilakukan perbaikan aplikasi, selanjutnya aplikasi akan melalui tahap distribution, aplikasi akan dimasukkan kedalam layanan Playstore agar dapat dijangkau lebih banyak orang. Tahap terakhir adalah maintenance dari aplikasi yang sudah di distribusikan, segala masukan dan keluhan yang diterima dari pengguna aplikasi akan ditampung dan akan menjadi feedback untuk melakukan update aplikasi kedepannya. 
Sampai dengan tahap akhir, aplikasi dapat berjalan dengan baik dan mampu memberikan informasi sesuai dengan yang diharapkan.

Hasil dari penyebaran kuesioner terhadap penilaian aplikasi media interaktif berbasis mobile mendapatkan hasil yang positif. Aplikasi dapat memberikan informasi artefak yang terdapat pada Museum Panca Yadnya dengan lengkap dan jelas. Parameter nilai yang didapat pada kuesioner adalah sangat setuju untuk setiap aspek yang ditanyakan. Aspek yang menjadi pertanyaan meliputi aspek tampilan, aspek suara, aspek manfaat.

Dengan cepatnya perkembangan teknologi yang ada saat ini, terdapat beberapa hal yang dapat ditambahkan dalam penelitian berikutnya. Dengan menggunakan Construct 2 dalam perancangan aplikasi ini, dapat ditambahkan berbagai pilihan game yang beragam sesuai dengan tema museum. Pengenalan artefak museum dapat dibuat dalam bentuk AR untuk lebih menarik pengguna aplikasi dalam pengenalan artefak museum.

\section{UCAPAN TERIMA KASIH}

Terimakasih disampaikan kepada Kemenristek Dikti. Kegiatan ini merupakan sebagian dari Program Kemitraan Masyarakat yang didanai oleh Kemenristek Dikti tahun 2019.

\section{DAFTAR PUSTAKA}

Andriyanto, I. (2016). Game Edukasi Pengenalan Rambu-Rambu Lalu Lintas Untuk Anak SD. Surakarta: Universitas Muhammadiyah Surakarta.

Arifin, J., \& Fadhlillah, M. R. (2017). Multimedia Interaktif Sebagai Media Informasi Mengenai Pengenalan Energi Alternatif. JESKOVSIA (Jurnal Desain Komunikasi Visual Asia), 1(1), 30-43.

Badan Pusat Statistik Provinsi Bali. (2019). Kunjungan Wisatawan Domestik ke Bali per Bulan 2004-2018. Retrieved July 30, 2019, from https://bali.bps.go.id/statictable/2018/02/09/29/kunjungan-wisatawandomestik-ke-bali-per-bulan-2004-2017.html

Badan Pusat Statistik Provinsi Bali. (2019b). Proyeksi Penduduk Provinsi Bali Menurut Kabupaten/Kota dan Jenis Kelamin, 2011-2020. Retrieved July 30, 2019, from https://bali.bps.go.id/dynamictable/2016/05/13/19/proyeksi-penduduk-provinsibali-menurut-kabupaten-kota-dan-jenis-kelamin-2011-2020.html

Banindro, B. S. (2019). Pengembangan Techno Virtual Berbasis Website sebagai Media Pembelajaran Rekayasa Visual Blender 3D bagi Mahasiswa Desain Produk. ANDHARUPA: Jurnal Desain Komunikasi Visual \& Multimedia, 5(01), 102-114.

Junaidi. (2010). Tabel $r$ - Prima-Pens. Retrieved July 30, 2019, from prima.lecturer.pens.ac.id/Pasca/tabel_r.pdf

Komala, R. D., \& Nellyaningsih. (2017). Tinjauan Implementasi Personal Selling Pada PT. Astra Internasional Daihatsu Astra Biz Center Bandung Pada Tahun 2017. Fakultas Ilmu Terapan Universitas Telkom, 3(2), 330-337.

Kusmanagara, Y., Marisa, F., \& Wijaya, I. D. (2018). Membangun Aplikasi Multimedia Interaktif Dengan Model Tutorial Sebagai Sarana Pembelajaran Bahasa Kanton. JIMP - Jurnal Informatika Merdeka Pasuruan, 3(2), 1-8.

LIPI. (2017). Jumlah pengunjung Kebun Raya LIPI tahun 2014-2017. Retrieved January 
18, 2019, from http://krbogor.lipi.go.id/id/download/unduh_berkas/72.html

LIPI, H. (2018). Kebun Raya Bali LIPI Buka Museum dan Taman PancaYadnya. Retrieved January 19, 2019, from http://lipi.go.id/berita/single/Kebun-Raya-Bali-LIPI-BukaMuseum-dan-Taman-PancaYadnya/20901

Maharani, P. (2018). Pengembangan Multimedia Pembelajaran Interaktif Menggunakan Construct 2 Tentang Suhu Dan Kalor Untuk Siswa Kelas X SMA. Lampung: Universitas Islam Negeri Raden Intan Lampung.

Nuryati. (2015). Pengaruh Komunikasi Sekolah Dengan Orang Tua Dan Peran Orang Tua Siswa Terhadap Hasil Belajar Muatan Matematika Semester Gasal Pada Kelas Rendah Di SD Negeri 1 Jagoan Tahun Pelajaran 2014/2015. Suarakarta: Universitas Muhammadiyah Surakarta.

Purnama, I. N., \& Ardyanti, A. A. A. P. (2017). Peramalan Kunjungan Wisatawan Di Obyek Wisata Bedugul Menggunakan Algoritma Fuzzy Time Series. SMARTICS Journal, $3(2), 55-58$.

Untoro, W. (2019). Pengembangan Metode Luther-Sutopo Dalam Pembuatan Game Edukasi Bedugul Forest. Denpasar: STMIK Primakara.

Zaharnita, E., Witarsa, \& Rosyid, R. (2016). Pemanfaatan Internet Sebagai Sumber Informasi Belajar Pada Mahasiswa Pendidikan Ekonomi Universitas Tanjungpura. Pendidikan Dan Pembelajaran, 5(9), 1-17. 